\title{
Integration, synergy and harmony of mining activity with tourism sector: utilization of tin tailing and mine reclamation program in the special economic zones
}

TR Wijaya PT TIMAH Tbk, Bangka Belitung Island, Indonesia

J Sudrajat Ministry of Energy and Mineral Resources, Indonesia

HA Octaviano Ministry of Energy and Mineral Resources, Indonesia

B Hutahaean PT TIMAH Tbk, Indonesia

R Adnis PT TIMAH Tbk, Indonesia

\begin{abstract}
While tin mining provides economic benefit to Indonesia generally there are also local area benefits where marine mining techniques allow for tailings to be used to increase the supply of land for coastal tourism development. Local area economic benefits from land reclamation and stabilisation using Cutter Suction Dredger (CSD) tin mining tailings are demonstrated for a case study at Bangka Belitung Island, Indonesia. Tin production increases along with the increasing demand for tin raw material, which can have significant environment impacts through landscape changes, lost biodiversity, and water contamination from mining activity. Conventional marine tin mining technique is done by combining the mining process with ore washing. The dredge will get the ore and dispose the tailing into the sea, which increases turbidity and reduces sea water quality. To accelerate environmental recovery, PT TIMAH Tbk uses CSD as a technological innovation in its mining process. The CSD process separates ore mining from ore washing, which reduces environmental risks and makes tailings available for land stabilization and reclamation. Mining is done at the sea, then the ore is transported by pipeline to the mainland. The remaining tailings are placed on land to be used as fill voids or to reclaim coastal land. Moreover, PT TIMAH Tbk is using CSD mining technology to accelerate their land reclamation program, which will expand the Tanjung Gunung coastal tourism area. CSD mining technology could support the development of Special Economic Zones (SEZs) in coastal areas, where land for development is in short supply, and tailings material is suitable for land reclamation and stabilisation. We conclude that using CSD technology, where land reclamation can support tourism development, harmonizes tin mining activity with the growth of tourism based on the cause study in Bangka Belitung Island
\end{abstract}

Keywords: Mine Reclamation; dredging; cutter suction dredge; sea mining; tourism; land reclamation; integration; harmony; Bangka Belitung Indonesia

\section{Introduction}

Along with the times and the depletion of tin resources on land, tin mining operations are now starting to shift towards the sea. Indonesia, as an archipelago, and Bangka Belitung Province in particular, besides having a huge potential in the tin mining sector, also has a huge potential for coastal tourism development if ecosystems are conserved. Tin mining activities in addition to generating financial benefits from the economic value of tin ore produced can have negative impacts on the environment. Changes in the landscape, loss of biodiversity and the decline in the potential of water resources are environmental issues that are the focus of various stakeholders, including Government and environmental NGOs (Chansang, 1988; Charlier, 2002). 
Standard marine tin mining operations dispose of tailings at sea with significant impact to benthic environments, corals and water quality. These activities affects the number of bottom sea benthic communities due to its sediment burial and increase of turbidity (Cruz-Motta \& Collins, 2004). At least $30-$ $70 \%$ of benthic species diversity reduction and $40-95 \%$ of benthic individual reduction come from tailing disposal and dredging operation (Newell, Seiderer, \& Hitchcock, 1998). Dredging and disposal activities int the sea in several countries in the sea caused corals mortalities due to the increasing of turbidity and injury to the corals (Erftemeijer, Riegl, Hoeksema, \& Todd, 2012). Increasing of turbidity and sediment plumes also reduces the water quality. Heavy metal contaminant such as $\mathrm{Pb}$ and $\mathrm{Zn}$ were found in the sea water in the vicinity tin mining in Thailand (Puttiwongrak et al., 2019), while in another area in Tanah Merah Island and Semujur Island of Bangka Belitung Island Province, increasing of water turbidity has reduced the number of fish in the area (Yusuf, Hudatwi, Adi, \& Robin, 2021).

Water quality and benthic decline have a direct impact to the food security of the community. There has been a decline in the fish species as the impact of the tin mining (Hortle \& Person, 1990). Moreover, the increasing of heavy metal contaminants such as $\mathrm{Fe}, \mathrm{Pb}$ and $\mathrm{Zn}$ in the environment due to tin mining also associated to the increasing of heavy metal bioaccumulation in the sea fauna like fish, squid and shrimp (Ashraf, Maah, \& Yusoff, 2012; Febrianto, Baskoro, Simbolon, \& Haluan, 2015). In the end, human health is affected by consuming the fisheries that have heavy metal contaminant above the threshold.

On shore mining activities in PT TIMAH Tbk have utilized bucket wheel dredge, cutter suction dredge and suction pontoon, which operates in 0-5 miles zone off the coast and disposing the tailing for years. PT TIMAH is innovating to change its mining equipment and working to realign its marine mining process to harmonize its operations with stakeholder interests in tourism development and environmental protection. One of PT TIMAH Tbk innovations is to mitigate environmental risks through use of an ore production ship with separate washing equipment, Cutter Suction Dredge (CSD) technology, for tin mining at sea. CSD is classified as suction boats, which can dredge almost all types of soil (sand, clay). In a CSD, the suction tube has a cutter head at the entrance of the sucker. The cutter can also be used for hard materials such as gravel or stone. Dredged material is sucked up by a centrifugal suction pump and removed through a pipe. Some CSDs have two spud cans on the back and two anchors on the front left and right. Spuds can be used as a CSD moving shaft, two anchors to pull left and right. Some CSDs use cables to manoeuvre when doing excavations.

PT TIMAH Tbk mining locations that use CSD vessels are located in Tanjung Gunung Village, Central Bangka Regency, Bangka Belitung Province, where the Tanjung Economic Tourism Special Economic Zone (SEZ) will be developed. So that the use of CSD technology is appropriate to synergizing and harmonizing mining corporation programs with the government programs for sustainable regional economic development. Currently the Tanjung Gunung Special Economic Zone is still in the process of approval due to problems overlapping with PT Timah Tbk's Mining Business License. Through the concept of collaboration with CSD mining technology, there will be a synergy and harmony between the Company and the Government.

SEZs are zones designed to attract companies to certain areas, in particular economically disadvantaged areas, by offering incentives, such as special tax treatment (Rustidja, Purnamawati, \& Setiawati, 2017). SEZ in Indonesia has been regulated since 2009 according to the Law Number 39 Year 2009 regarding Special Economic Zones. Government of Bangka Belitung Island province saw this opportunity, and therefore they propose Tanjung Gunung as one of the SEZ in 2017, to attract investment and increase local revenue. SEZ Tanjung Gunung is designed as one of the biggest tourist attractions in Bangka Belitung Island Province, which consist of several areas as seen in Figure 1 and offer tourism attraction from PT TIMAH Tbk Reclamation programs. 


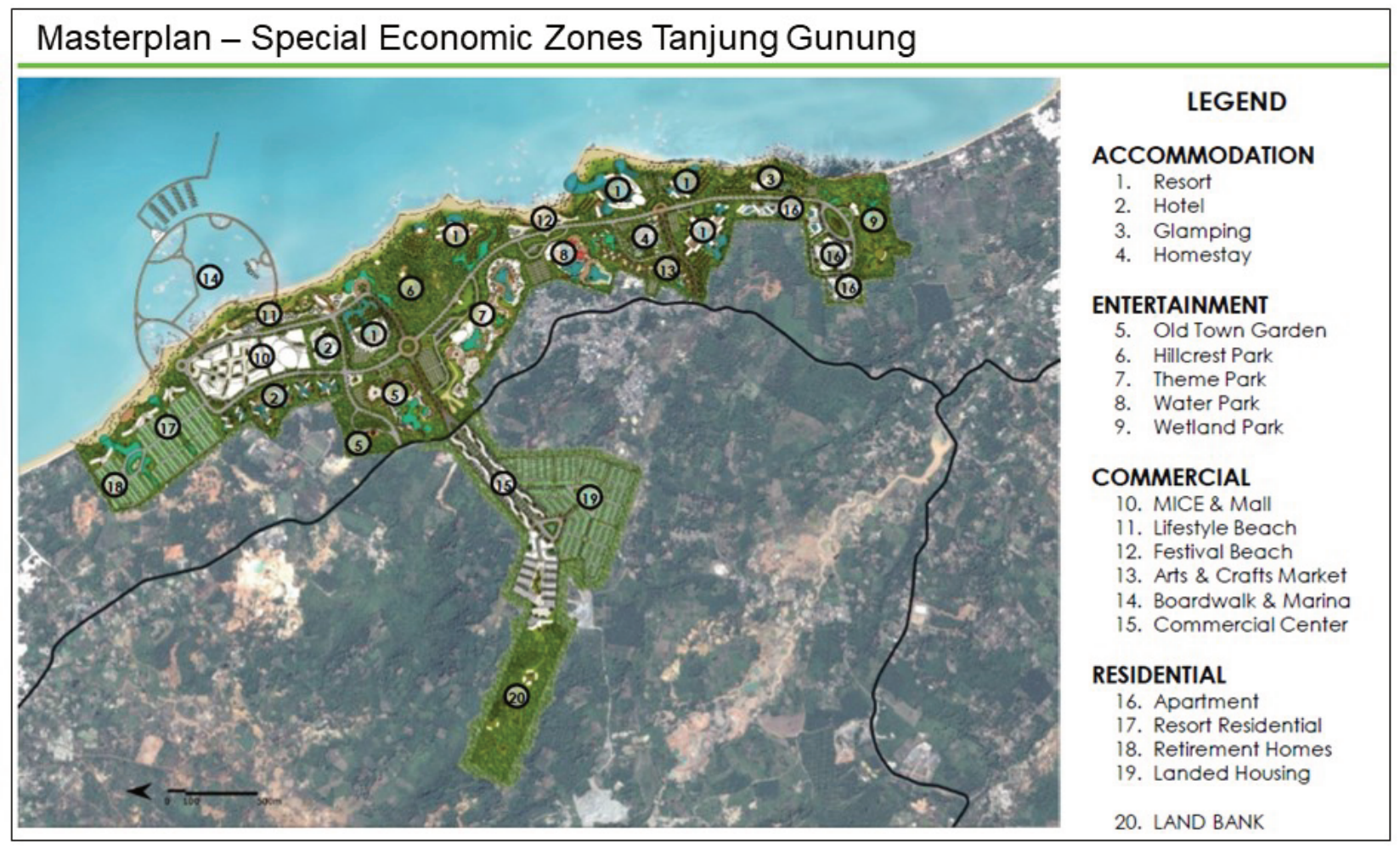

\section{Figure 1 Masterplan of Special Economic Zones Tanjung Gunung}

Based on the Minister of Energy and Mineral Resources Regulation Number 26 year 2018 concerning Implementation of Good Mining Rules and Supervision of Mineral and Coal Mining, and Minister of Energy and Mineral Resources Decree Number. 1827K / 30 / MEM / 2018 concerning Guidelines for the Implementation of Good Mining Rules, that the reclamation activities to be carried out are based on the Land and Sea Reclamation Plan Documents prepared by PT TIMAH Tbk and approved by the Ministry of Energy and Mineral Resources. The PT TIMAH Tbk mining reclamation program has been properly overviewed and agreed by both the government and corporation.

Tanjung Gunung SEZ needs material to expand the coast and construct several tourism buildings, where CSD boat can continuously supply the material. All CSD boat's activities in water are monitored through a computer, i.e., draghead movement, CSD angle and pressure on the exhaust pipe. All of the material is channelled through the pipe into the land. CSD mining operations (Figure 2) in addition to increasing the volume and quality of production also reduce risk to the environment, allowing the ore extraction process carried out at sea to be separated from the washing process is carried out on land. By using CSD vessels, the ore material can be mined from the sea floor and pumped to the run of mine stockpile on land as a slurry conveying media in a floating pipe to begin the washing process at the washing plant facility. 


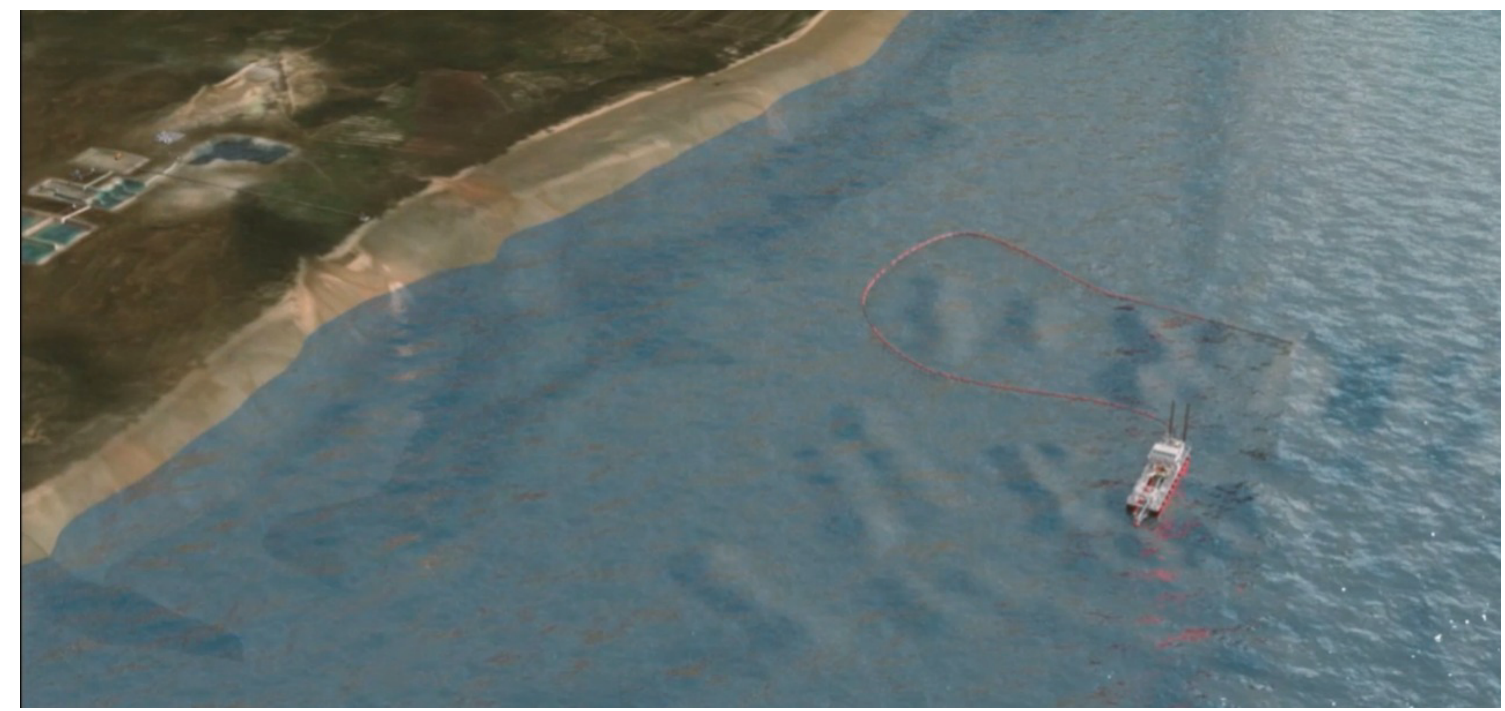

\section{Figure 2 The position of CSD in mining operation}

Since mining activities with CSD disturb areas at sea and on land, reclamation activities and the process to rehabilitate the disturbance are carried out both at sea and on land as instructed by the government. Reclamation activities at sea include coral transplantation, artificial reef/fish shelter construction, and monitoring of marine water quality. Reclamation activities on land include land arrangement, coastal expansion and revegetation.

\section{$2 \quad$ Methodology}

\subsection{Cutter Suction Dredge Operations}

CSD is an efficient tool for proper dredging in hard and shallow water. Before dredging, the foot spud is lowered to support the ship. Dredging is done using a cutter head that rotates at the end of a hinged ladder that was previously lowered to the seabed (Figure 3). The CSD's spud leg system is able to hold the cutter simply in dredging, even in hard soil.

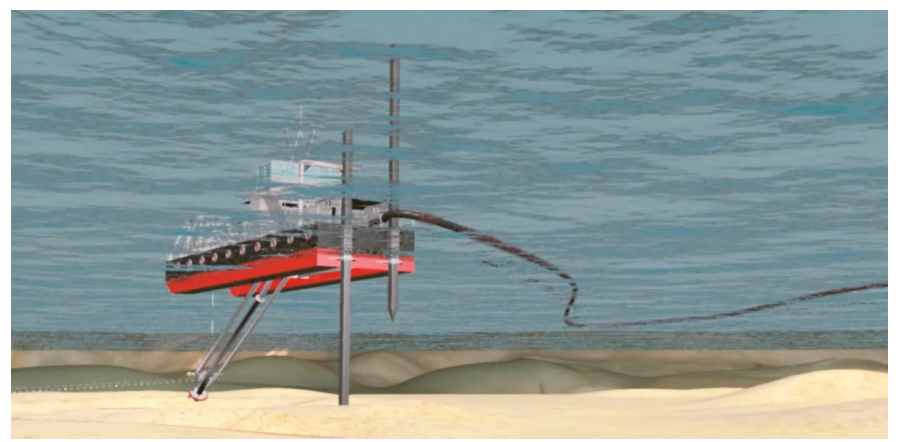

\section{Figure 3 Spud leg to support CSD}

CSD can dredge various types of soil material, according to the ability of the dredging pump and its cutter head. An important part of the CSD dredger that affects production is the pump power, cutter head and the ability to move the ship (Figure 4) 

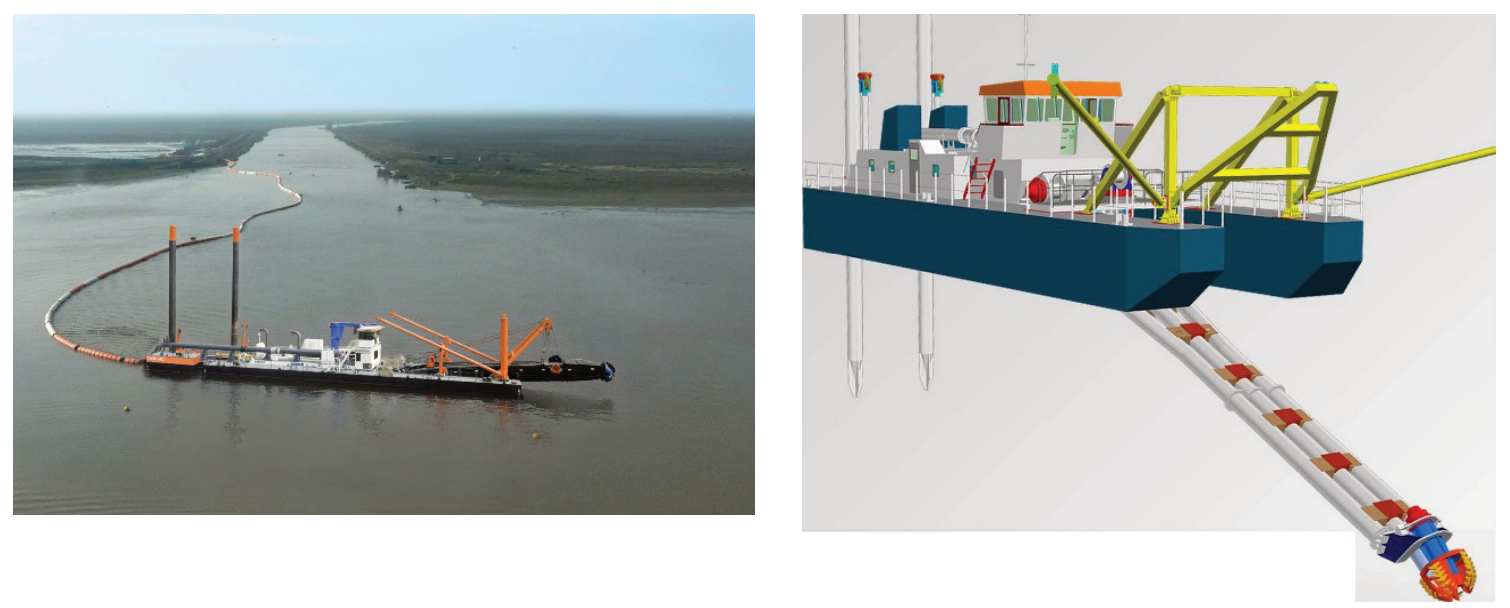

\section{Figure 4 Cutter Suction Dredger (CSD)}

Seabed material is divided into 2 types, Overburden (OB) and Ore (Kaksa) material. CSD will suck OB and ore by using a ground pump. CSD transfers OB to the location of overburden dumps (dumping area) with the delivery media in the form of floating pipes (floating pipes). While another floating pipe transfers the ore material (kaksa) to the stockpile on land and then the washing process at the washing plant facility begins.

The process of ore washing in the washing facility as seen in Figures 5 and 6 are

1. The ore material in the stockpile will be fed to the washing plant by utilizing the high difference between the stockpile and the washing hole by spraying it to form a slurry and assisted with a push from the bulldozer so that the material enters the washing hole and is ready to be pumped and fed into the washing facility.

2. Material flows through pipes to enter the rotary filter to be processed based on its size (sizing), where the material with a small size or undersize material will become a bait for jigs and large size material or oversize material flows directly into the tailings pond.

3. The undersize material will be reprocessed by the jig utilizing the difference in the specific gravity of the material to be separated. Jigs are also equipped with a mechanism that causes pressure and suction which is balanced using additional water in the form of a diaphragm or piston driven from the motor through an eccentric.

4. The results of processing in the washing plant are $30-40 \%$ of tin content. The concentrate from the jig separation will then be collected and stored for later sent to the Tin Ore Processing Centre. 


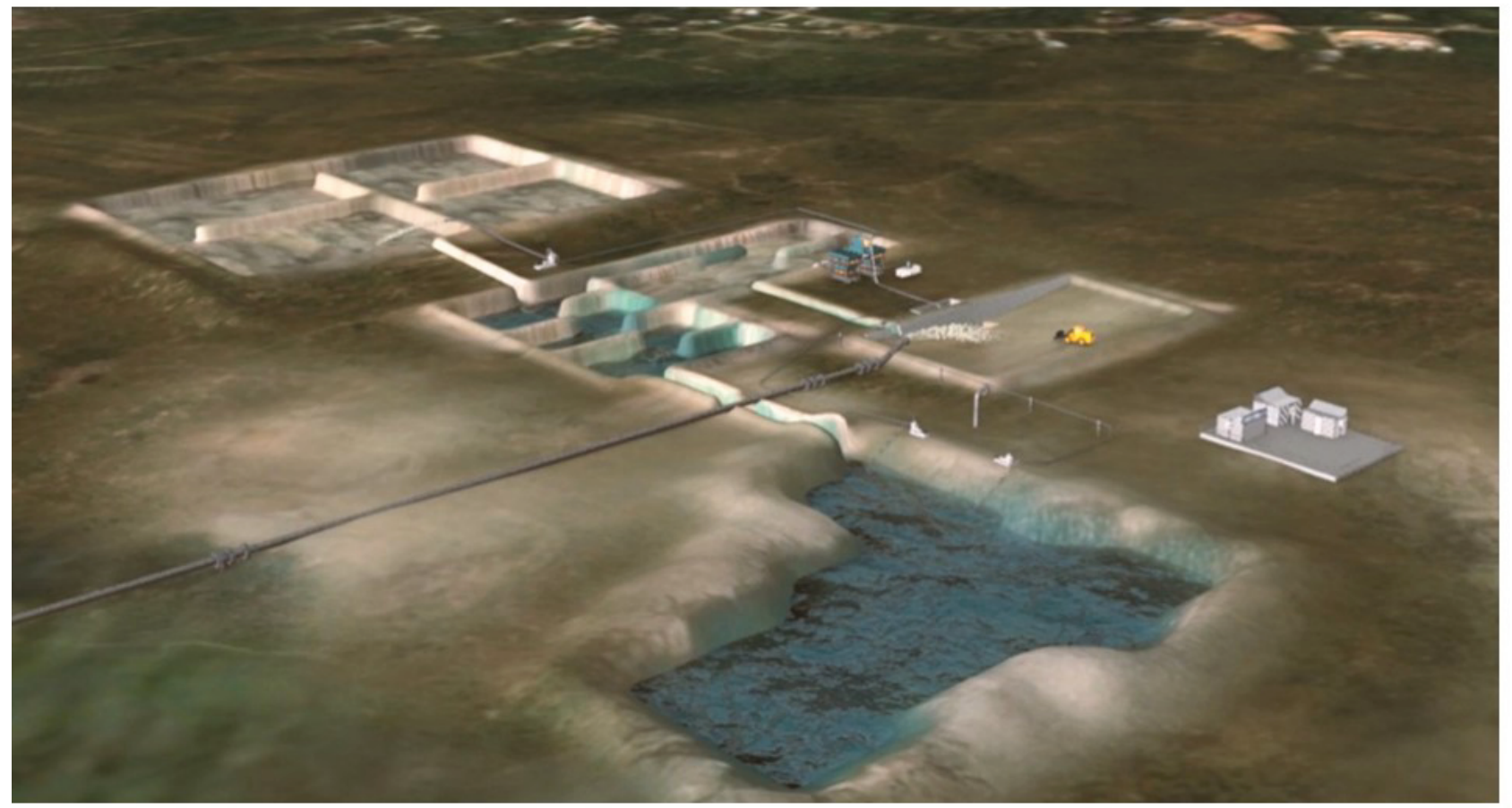

\section{Figure 5 Illustration of processing at a washing plant (1)}

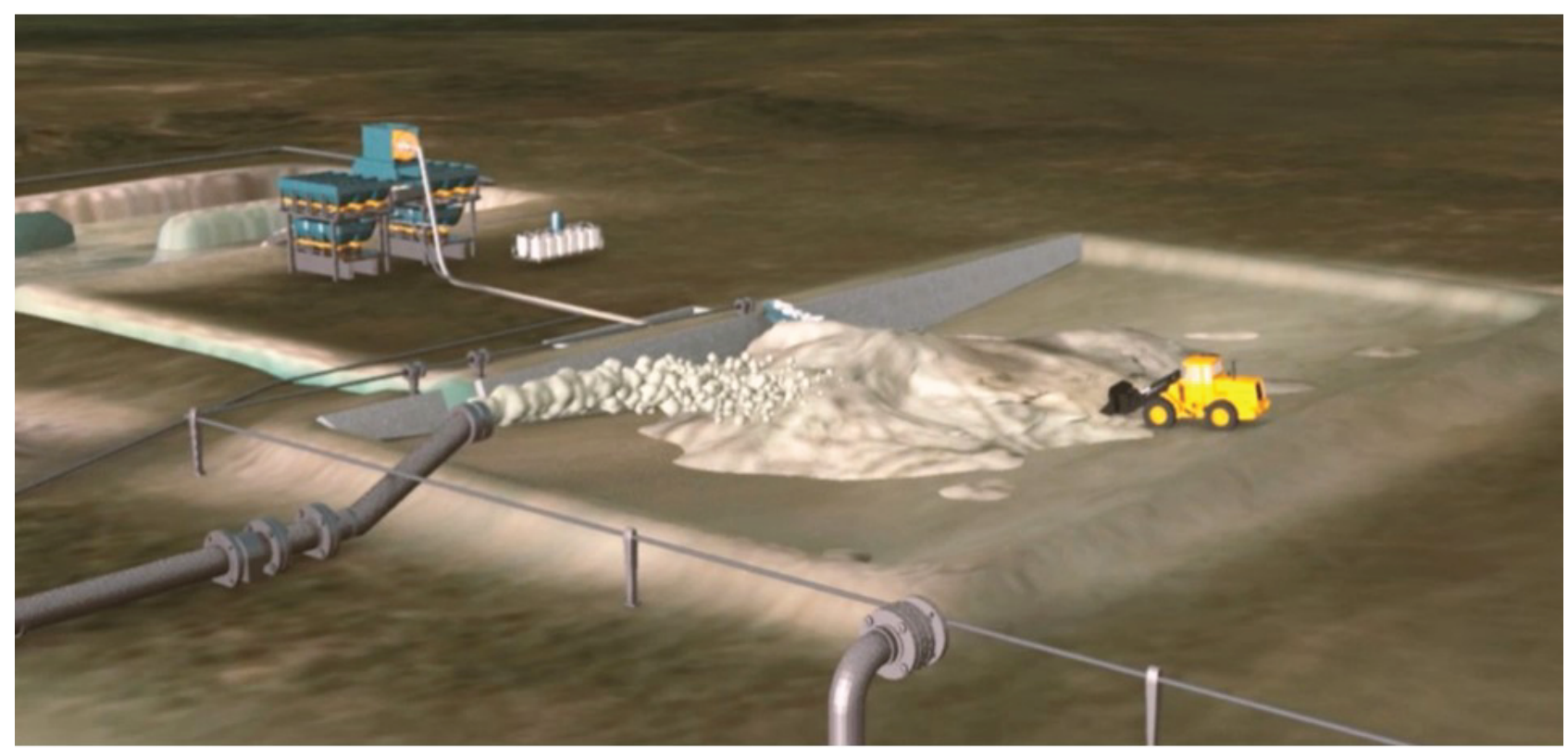

\section{Figure 6 Illustration of processing at a washing plant (2)}

This mining process will also produce $O B$ and processed tailings material. $O B$ material will be placed at a specified stockpile area, but it can also be used as a reclamation area on the coast or in the SEZ. Reclamation activities are one of the actions chosen by the government to provide urban land needs for the SEZ. The results of the reclamation activities are known as the Waterfront City concept, while the processed tailings material will be transported to the tailings pond, making it easier for treatment. The tailings material can be extracted and stockpiled or used for levelling the land area around the SEZ. 


\subsection{Water Conditions Around the CSD Mining Location (Rebo Beach)}

PT TIMAH Tbk baseline water quality survey was done at the time during the preparation for the sea reclamation plan document, including the waters around the mining of this CSD method, namely Rebo beach (see Figure 7). Some observed parameters are the condition of the bottom substrate closure, the condition of reef fish, and the condition of benthic biota.

In general, environmental conditions in the waters of Rebo Beach have a sloping water contour with live coral conditions in the waters ranging from $75.40 \%$, which can be categorized very well. However, the impact of mining activities caused most of the live coral in the waters of Rebo Beach to be exposed to sedimentation. According to the survey results that the highest sedimentation exposure in the waters of Bangka Regency was in Rebo Beach, which is an abiotic cover of $11.36 \%$ with a mud bottom substrate; biotics 3.96\%; 9.28\% dead coral.

The condition of reef fishes on the Rebo beach can be identified by the index H' (Diversity), E (Uniformity), $\mathrm{C}$ (Dominance), and $\mathrm{N}$ (Abundance). The results of a survey of reef fish communities that have been carried out in the waters of Rebo Beach show the index values of $\mathrm{H}^{\prime}, \mathrm{E}, \mathrm{C}$, and $\mathrm{N}$ in sequence are 2.18; $0.78 ; 0.17$; 318 ind $/ 100 \mathrm{~m}^{2}$. The $\mathrm{H}^{\prime}$ index of 2.18 shows the level of distribution and stability of the community in a moderate position (Syari et al., 2019). Then the index value of 0.78 indicates that the community in these waters is stable (Syari et al., 2019). While the $C$ index value of 0.17 indicates low dominance (Syari et al., 2019). For an abundance of 318 ind / $100 \mathrm{~m} 2$ it is sufficient.

The structure of benthic biota communities in Rebo beach is indicated by the index values $\mathrm{H}^{\prime}, \mathrm{E}, \mathrm{C}$, and $\mathrm{N}$ sequentially the same value as the reef fish community because the reef fish community is included in the benthic biota in a waters

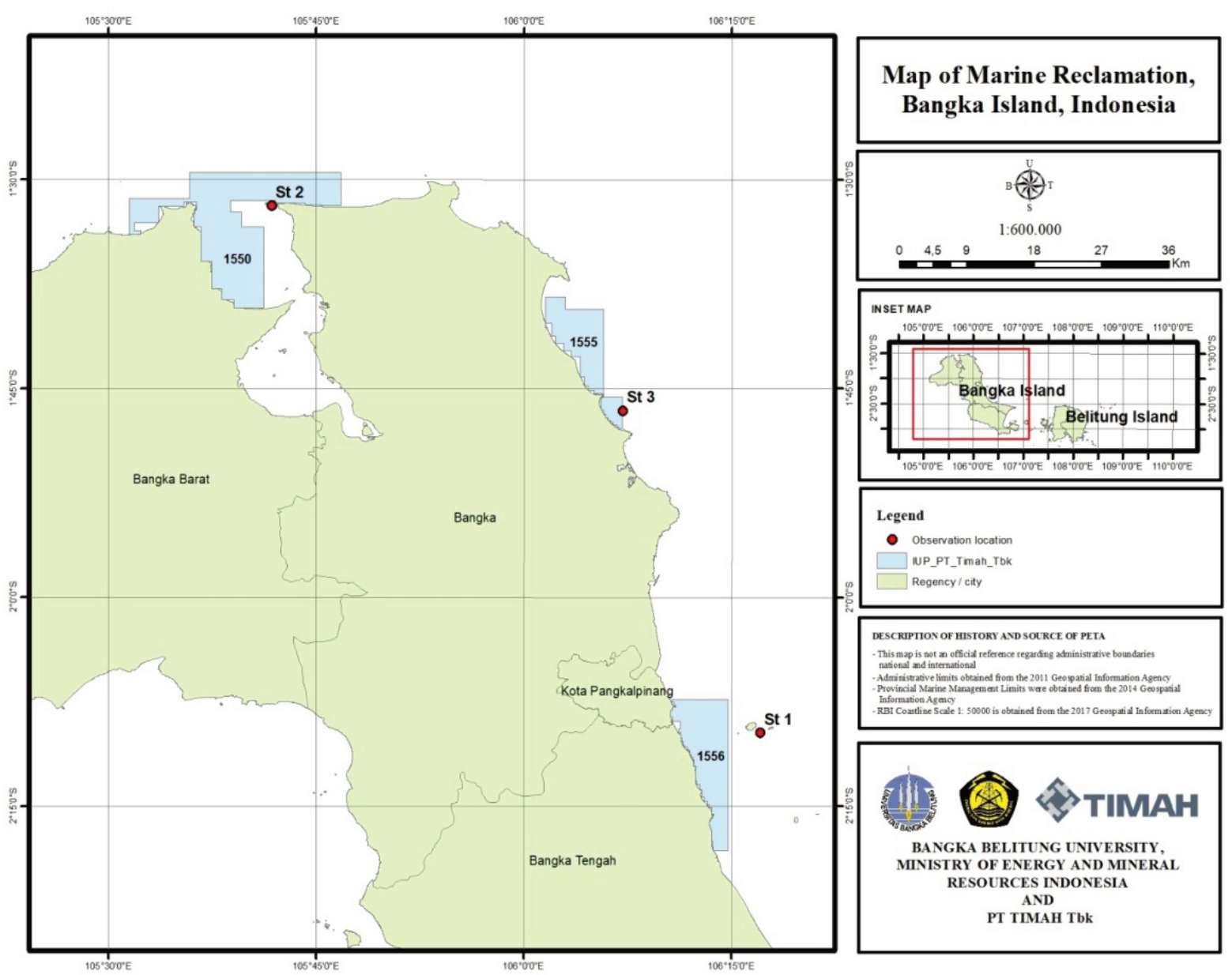

Figure 7 Survey map 
The survey was carried out at a predetermined point as in the map above, namely at the St 1 point and on the coast or washing plant area. Because of two different points, namely at sea and on land, the survey at sea was carried out by the diving method while the survey on land used direct observation in the field.

\section{$3 \quad$ Result and Discussion}

\subsection{Site Conditions of Former Mine Land Using CSD Method}

Tin mining activities using marine tin mining tools such as CSD produce residual tailings that can potentially be used as land reclamation material (Figure 8).

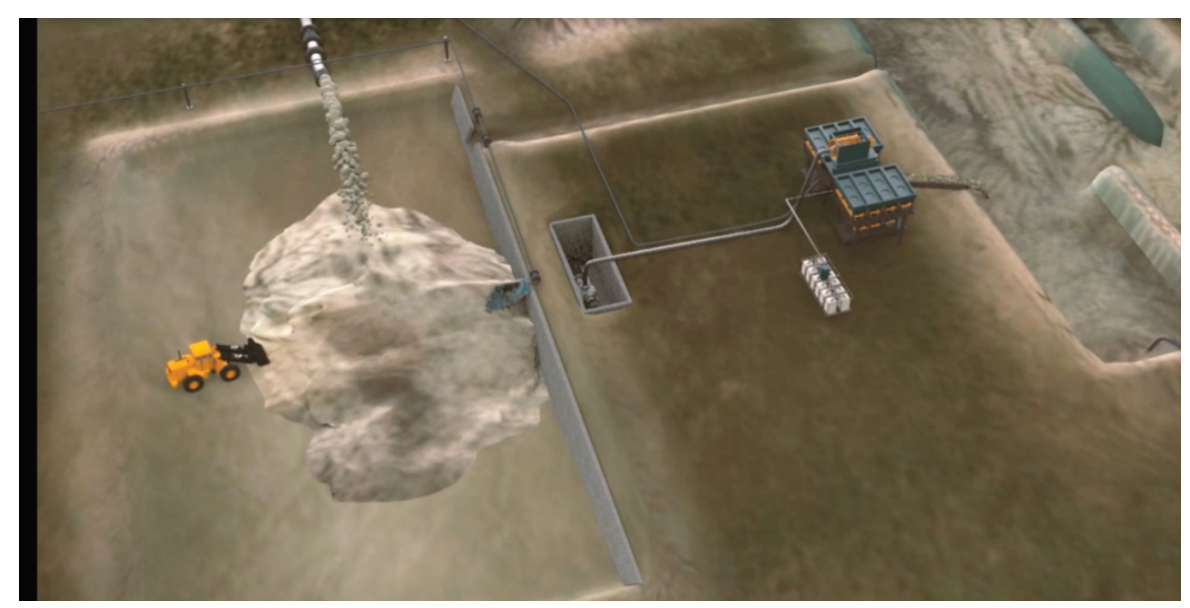

Figure $8 \quad$ Illustration of tailings use in the land reclamation process

The reclamation will be applied with a combination of a polder system and a fill system. The polder system is by encompassing a wetland (puddle) with a water-resistant embankment for example Geotube to reduce the ground water level in the area. Furthermore, controlling the water level is important consolidate tailings by maintaining a desired water content threshold so that the reclaimed land is dry and trafficable.

The success of this system relies on maintaining the water level, which can be managed with a pump. The system has advantages where the volume of landfill needed for land reclamation is very small, especially if the land does not need to be elevated. The drawback is that the construction of embankments, canal systems and pump systems is relatively expensive. In addition, the tailings consolidation process for land reclamation is relatively slow in relation to land development pressure. After the landfill is consolidated, then the tailings deposition is repeated until the desired land level is attained. In addition to using earth embankments for land fill operations, geotubes are used to construct coastal embankments to reclaim coastal land using tailings as fill (Figure 9).

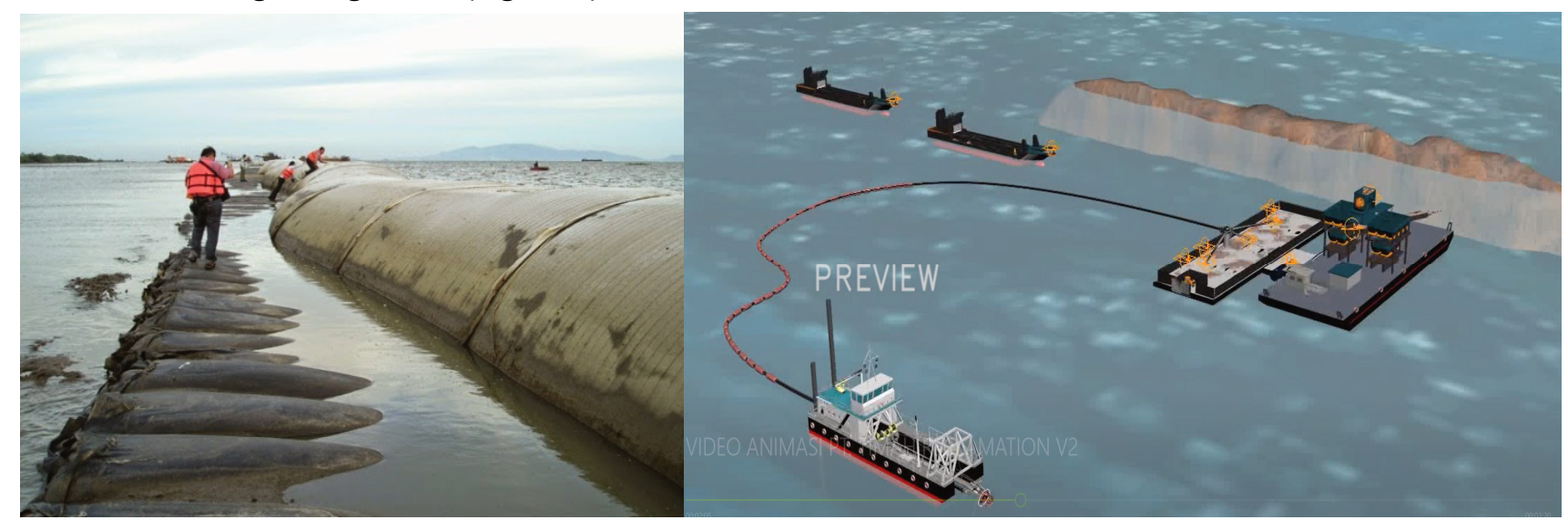

Figure 9 A polder system using geotubes and a fill system 


\subsection{Reclamation plan Program - synergy and harmony with tourism}

To mitigate environmental impacts from the marine tin mining process by using CSD method, while addressing the development of SEZ (Special Econonomic Zone) at the mining location, PT TIMAH Tbk also stipulates reclamation activities including:

1. Reclamation at sea through coral transplantation and sinking of fish shelter;

2. Reclamation on the coast / land by planting coastal plants (mangroves and coastal plants);

3. Underwater and coastal education activities including diving and mangrove tours of the reclaimed areas in to synergize and harmonise mining activities with SEZ development objectives.

It is intended that PT TIMAH Tbk be capable of producing the sustainable reclamation programs with stakeholder support, including involving the surrounding community in reclamation work and maintenance.

\subsubsection{Coral Transplantation}

Coral transplantation is one of the marine reclamation/rehabilitation programs are needed in former tin mining areas in the waters of Rebo Beach, based on our knowledge of water quality and benthic habitat degradation from historical mining activity. Specifically, this coral transplantation is intended to rehabilitate the coral reef ecosystem in Rebo beach. The strategy for implementing this activity is staged as: preparation, socialization, implementation, and monitoring \& Evaluation phase. The preparation phase is to prepare all available resources for smooth coral transplantation. The resources that can be prepared are including SCUBA diving equipment, callipers / calliper, GPS, underwater stationery (slate), buckets / baskets, ropes, underwater cameras, transplantation media. The design of transplant media that is commonly used is like in Figure 10 and 11.
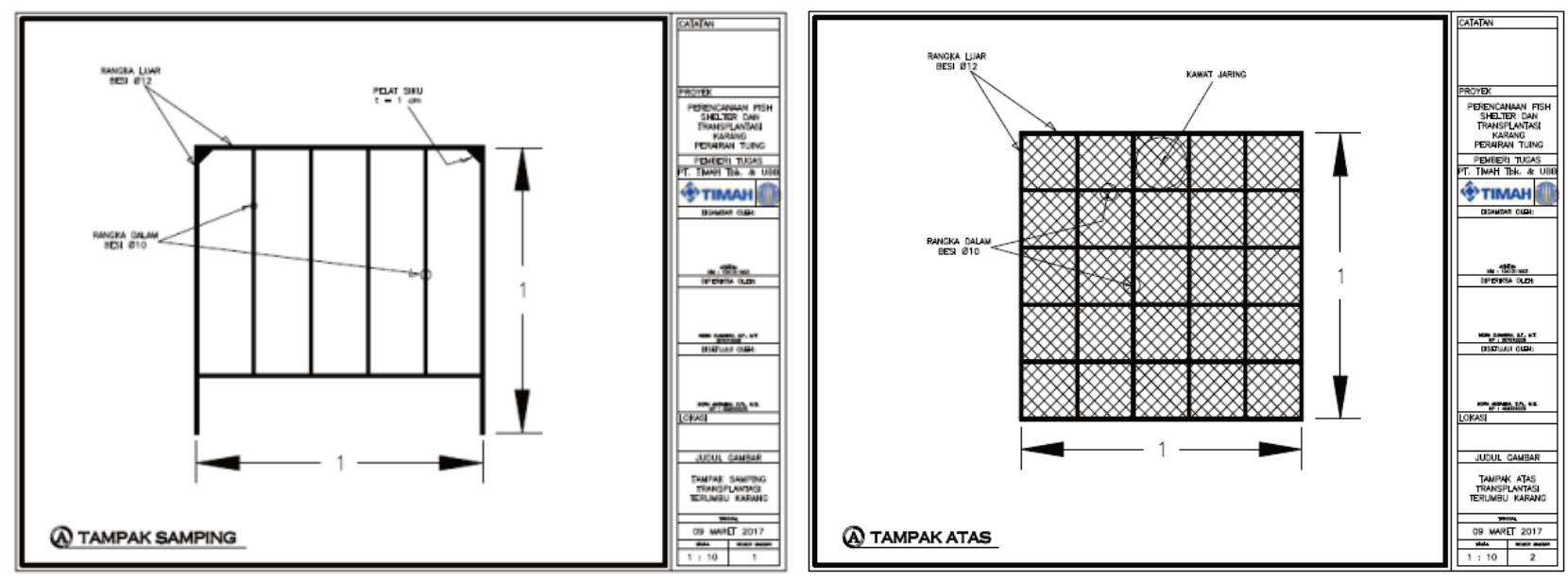

Figure 10 Coral transplantation media design 


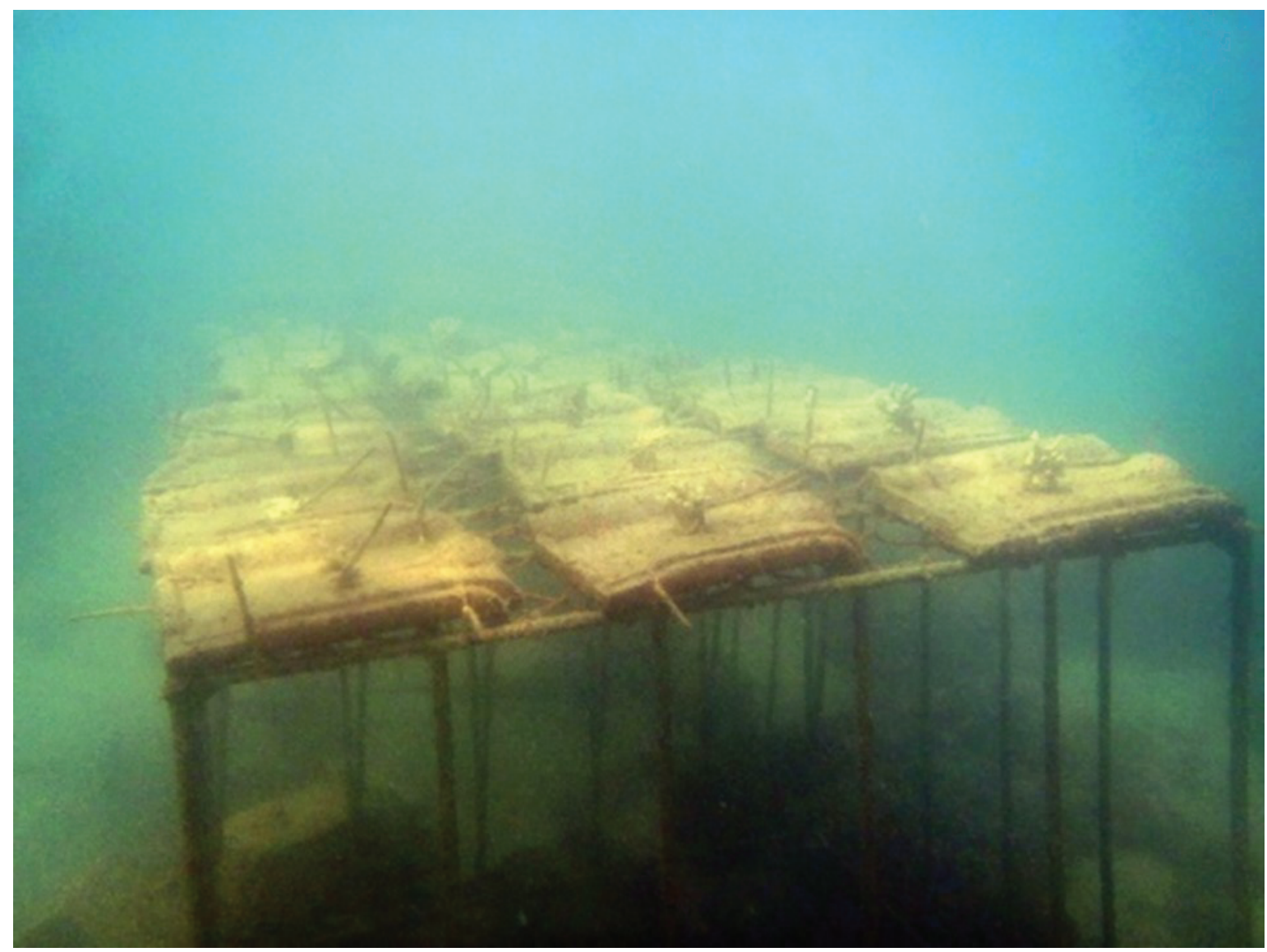

\section{Figure 11 Coral Transplantation Media}

\subsubsection{Sinking of Fish Shelter}

Fish shelter media are designed to attract fish around the placement location and are expected to become a place for fish development to increase the abundance and diversity of fish and form coral reefs. This fish shelter is also intended as an artificial habitat for fish as a substitute for coral reefs. This design uses a hemisphere, which is a symbol characteristic of the Bangka Belitung Islands (Figure 12 and 13).

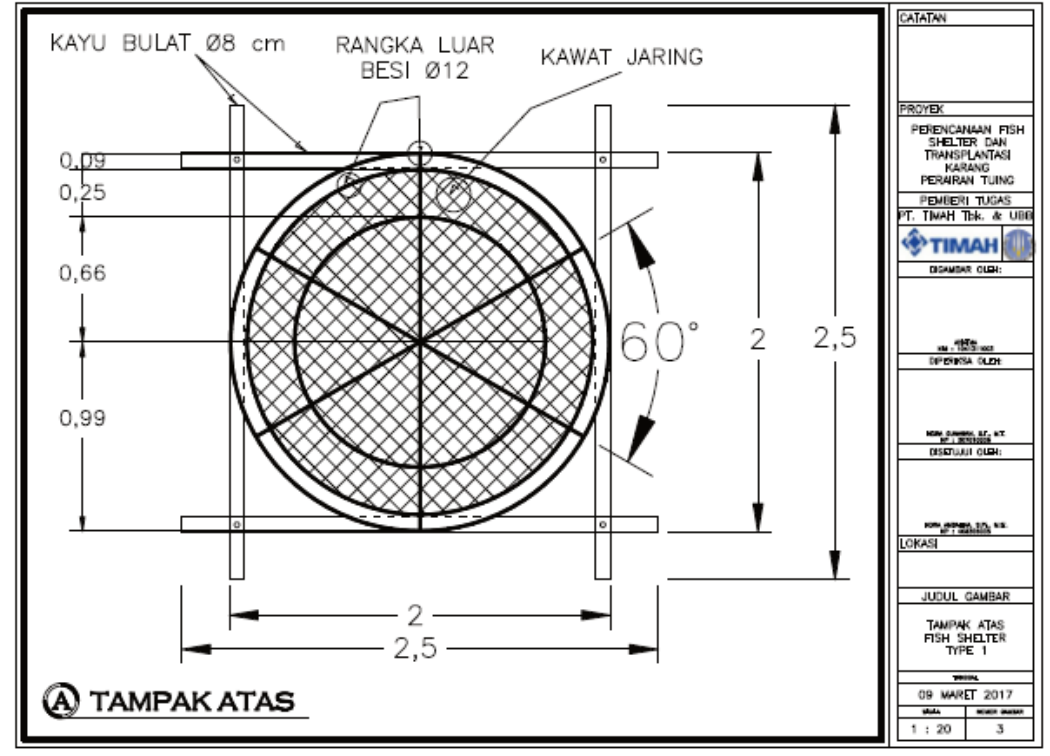

Figure 12 Fish Shelter Design 


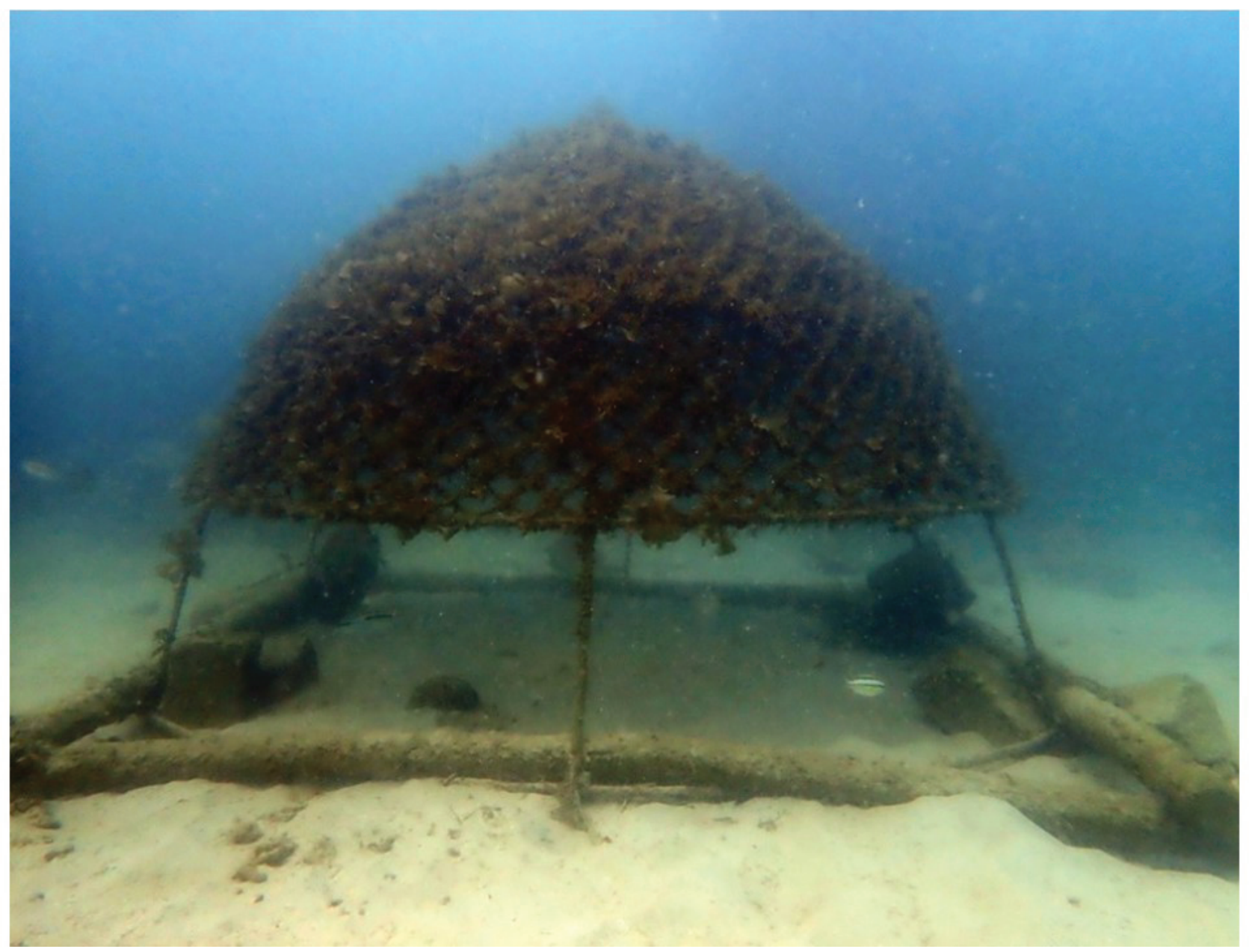

\section{Figure 13 Fish Shelter}

Preparations phase considerations in the process of sinking fish shelters include SCUBA diving equipment, GPS, underwater stationery (slate), ballast (sinker), rope, underwater camera.

\subsubsection{Mangrove plantation}

The location of mangrove planting is based on the coastal area impacted by the marine mining process, the specified land stockpiling area, and area on the coast where the washing plant was formerly located. Naturally pioneering mangrove species that are found to occur at these sites will be enriched with supplementary plantings. Because it will be very difficult to grow for mangrove seedlings which are directly hit by the waves. Types of mangrove plants that are commonly used include types of Rhizophora $s p$. (mangrove plants), Sonneratia sp. (perepat plants), Avicennia sp. (Fires). Two planting methods namely the spacing method (usually $2 \mathrm{~m} \times 1 \mathrm{~m}$ ) and the cluster / group method (Figure 14 and 15 ) will be used at these locations. 


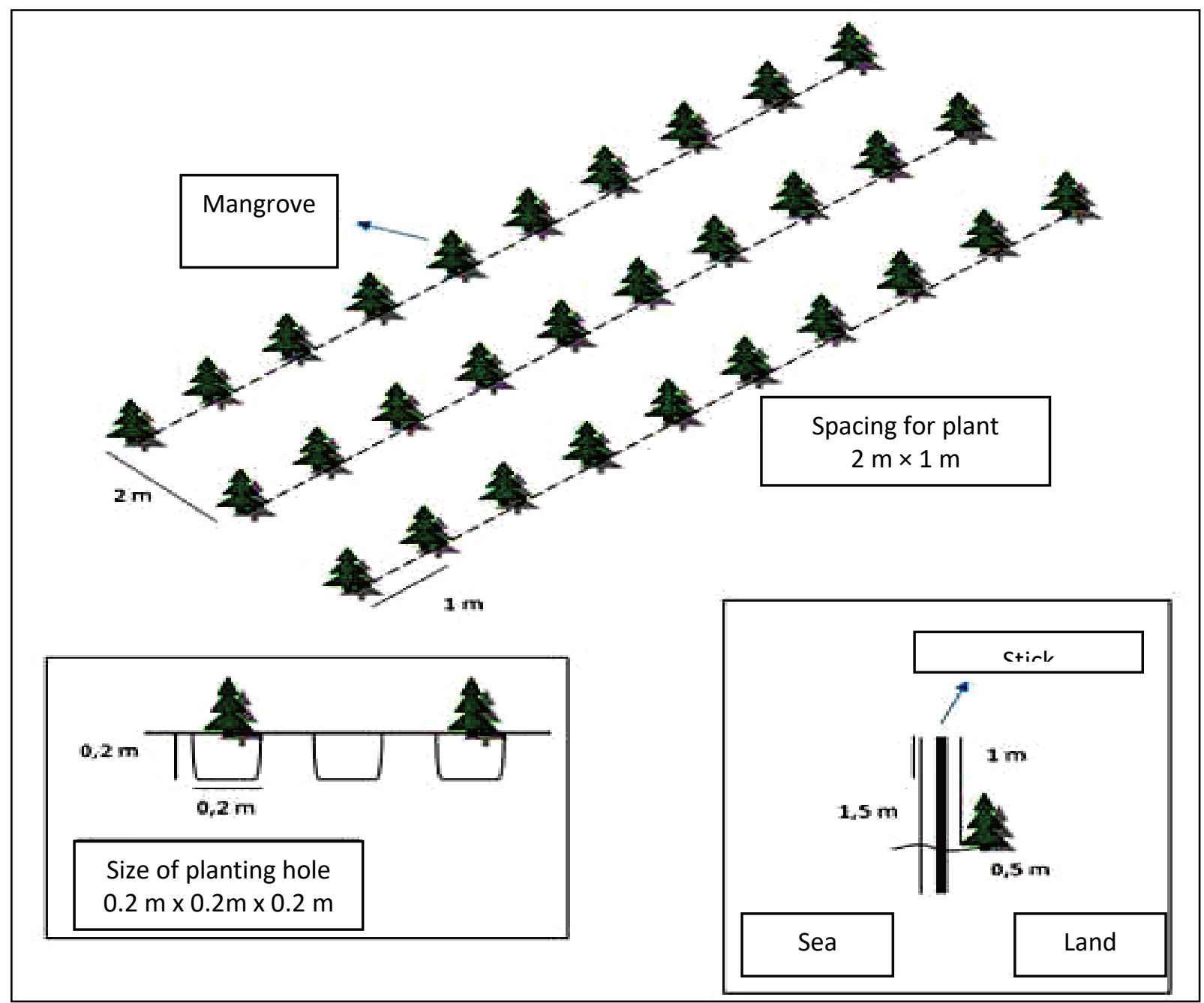

Figure 14 Mangrove Plantation Design

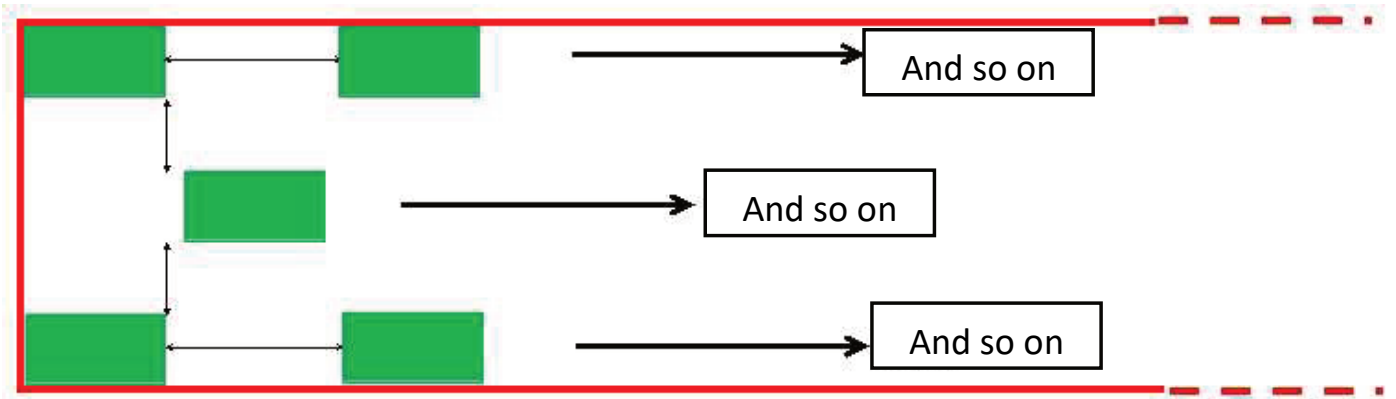

A group of mangroves

\section{Figure 15 Clustering design for Mangrove plantation}

In addition, mangrove planting can use a pond intercropping system to optimize and support capacity development and community empowerment and to help preserve biodiversity. This will require community cooperation and synergy to sustain the planting program at the former washing plant location.

Revegetation in other reclaimed areas with a variety of coastal plants such as Casuarina equisetifolia (Cypress Sea) and Terminalia catappa (Ketapang) will be appropriate to habitat. Unlike the case of 
mangrove planting, planting of coastal plants is sparser with a minimum spacing of $4 \mathrm{~m} \times 4 \mathrm{~m}$, but usually done with a spacing of $5 \mathrm{~m} \times 5 \mathrm{~m}$ in consideration of the development of roots supporting larger tree canopies up to a diameter of $5 \mathrm{~m}$.

\subsubsection{Underwater and Coastal Education Tourism}

To support the development of the SEZ tourism in the CSD mining location, the former sea mining areas will be restored. The restoration area is intended to be used for tourism activities including, underwater education/diving spot, to demonstrate the effects of coral transplanting and fish shelters on environmental quality after tin mining. The activity is intended for licensed divers (Figure 16).
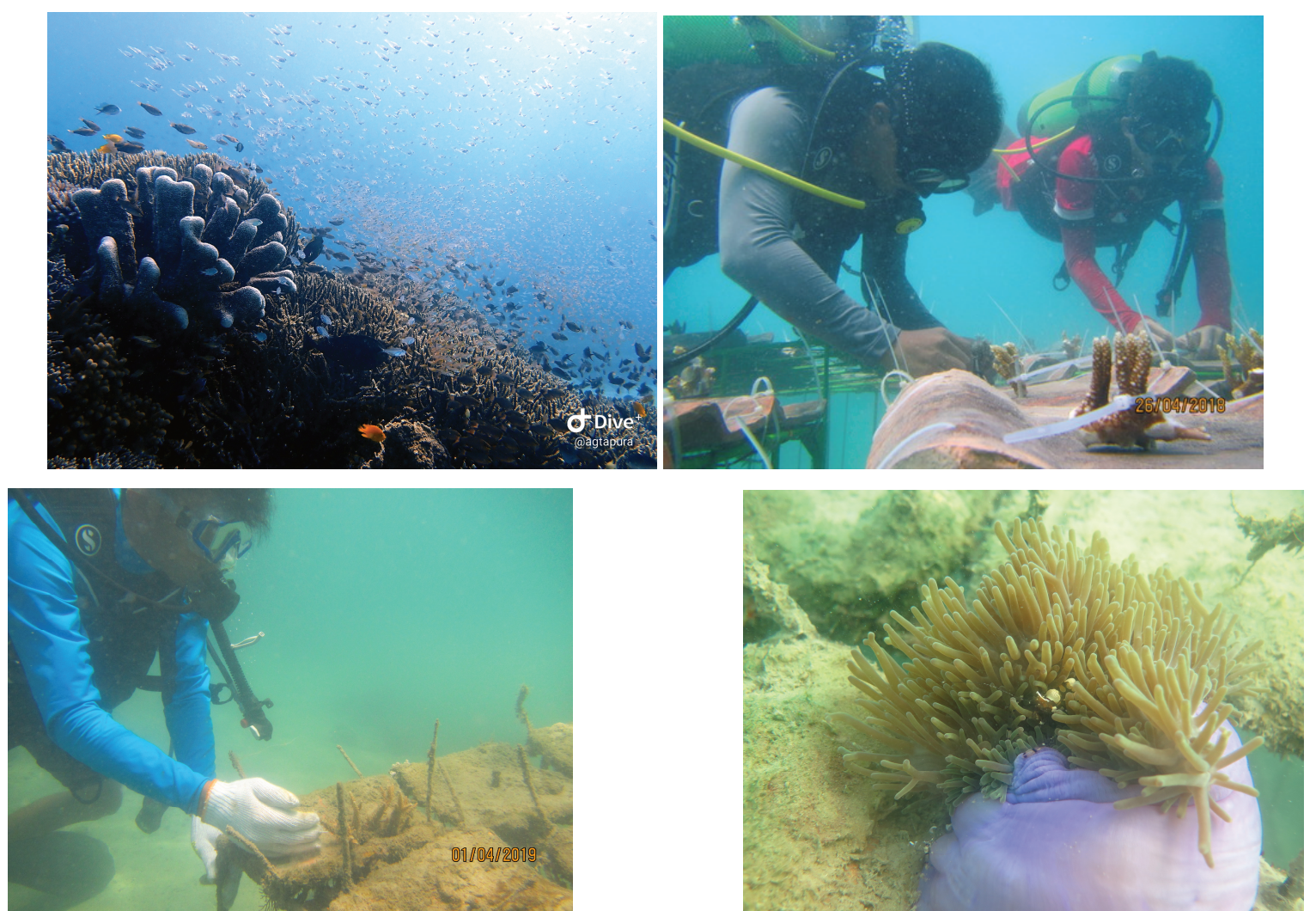

\section{Figure 16 Diving spot and under water education}

In addition to underwater education/spot diving, reclamation activities will also align with terrestrial tourist destinations. The island of Bangka Belitung has existing coastal tourism infrastructure with public interest in diving spots, beaches and mangrove tourism. In line with the development of SEZ in this location, one of the reclamation programs for coastal tourism destinations is the development of coastal education tourism.

Mangrove ecosystems are the key ecosystems supporting life in coastal areas. They have a unique function in the environment. Because of the influence of the sea and land, mangroves are able to act as a barrier to the waves and a barrier to intrusion and abrasion of sea water. Mangrove forests are also a source of income for rural communities in coastal areas, where they are identified with marine biota and coastal flora and fauna conservation, with potential for ecotourism, education and research.

The intent of the reclamation work is that when revegetated mangrove areas are opened for ecotourism in accordance with the principle of ecotourism, they can increase the income of the surrounding community and be an educational resource about the importance of conserving mangroves and other coastal ecosystems. Another advantage of mangrove ecotourism activities for the surrounding community is that the local fishery is more able to provide fish to support community requirements into the future (Figure 17). 

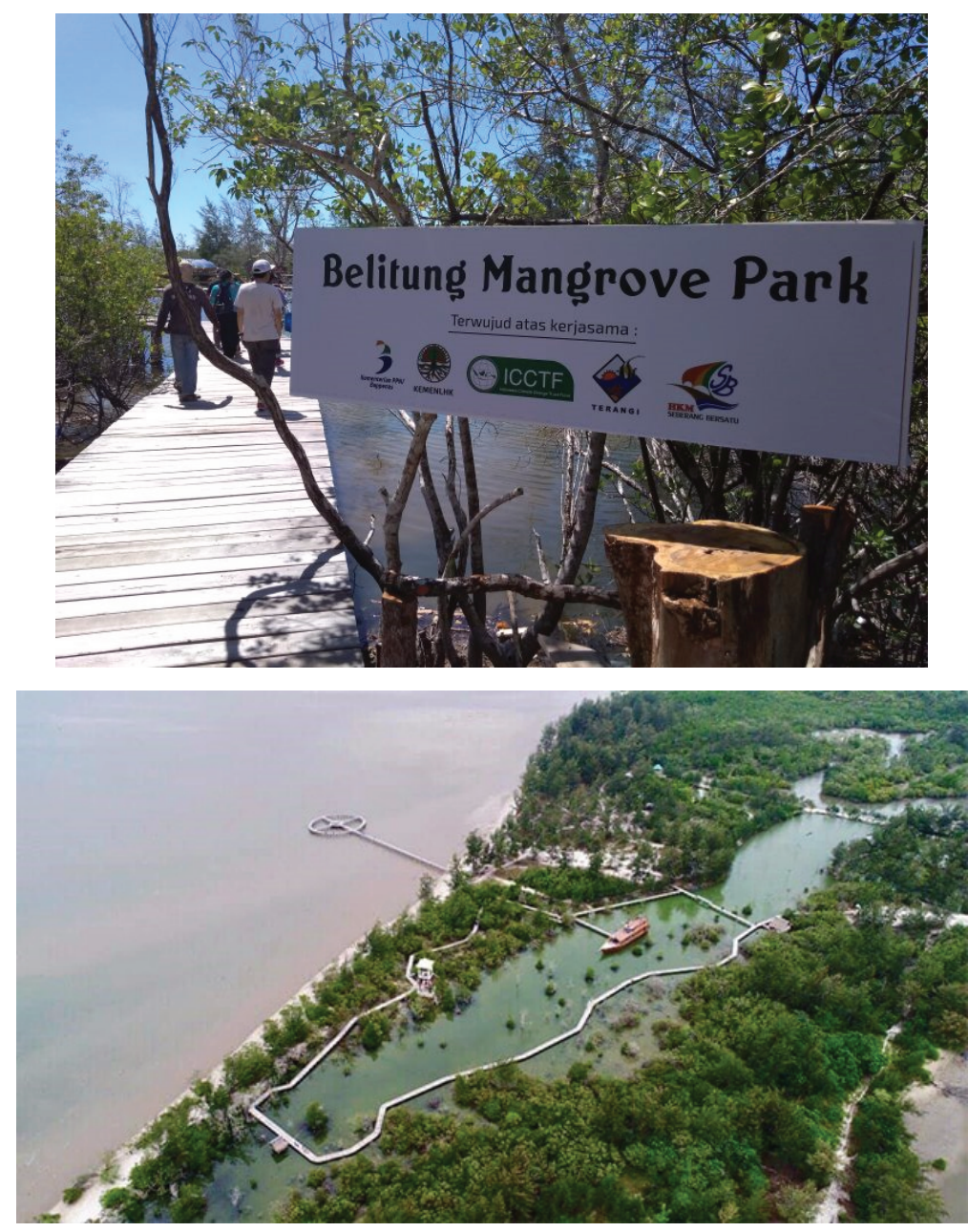

Figure 17 Example of coastal education area (Fariansyah, 2019)

\section{Conclusion}

Based on the case study of PT TIMAH Tbk marine tin mining using Cutter Suction Dredger vessels (CSD), there are potential development synergies between marine tin mining, eco-tourism and community development objectives in coastal Special Economic Zones (SEZs) in Indonesia. The opportunities for marine tin mining to be harmonized with eco-tourism and local community development in the Tanjung Economic Tourism SEZ, Central Bangka Regency, Bangka Belitung Province can demonstrate local economic, environmental and social benefits that address Government, NGO and local community needs. CSD mining technology will support successful land reclamation and marine rehabilitation programs. Tin mining using CSD technology can provide Government with fill material to reclaim and stabilise coastal land to expand the SEZ area and support economic development. CSD technology separates tin ore washing from the marine mining process so that marine area rehabilitation and coastal revegetation programs can be implemented to mitigate environmental impacts from mining and support development objectives. The programs see former marine mined areas rehabilitated by coral transplanting and fish shelters to recreate reef habitats, and mangrove and coastal habitat revegetation in areas disturbed by tailings, overburden stockpiles, land reclamation and washing plant infrastructure that will reduce coastal erosion and restore important coastal and marine ecosystems for eco-tourism and sustaining village fishery.

The next step will be to coordinate company mining plans with the local government tourism development programs, with the aims of increasing local community income while restoring the environment. Also, monitoring and maintenance programs are needed to manage rehabilitated areas. Government regulation 
and signage is needed to socialise the local people to preserve environmental quality in rehabilitated areas. The economic benefits from mining rehabilitation and land reclamation efforts also need to be assessed from the area. The benefit cost analysis would support extension of the mining and rehabilitation approach in other SEZs with marine mineral resources.

\section{Acknowledgement}

The authors wish to thank those who have contributed to our research. Also, special thanks and appreciation go to Dr Lana Saria, Director of Engineering and Environmental Mineral and Coal, Ministry of Energy and Mineral Resources, and Mr Agung Pratama, Director of Operations and Production, PT TIMAH Tbk for their valuable support for this research.

\section{References}

Ashraf, MA, Maah, MJ, \& Yusoff, I 2012, 'Bioaccumulation of heavy metals in fish species collected from former tin mining catchment'. International Journal of Environmental Research (IJER), vol. 6, no. 1, pp. 209-218.

Chansang, H 1988, 'Coastal tin mining and marine pollution in Thailand'. Ambio, vol. 17, no. 3, pp. 223-228.

Charlier, RH 2002, 'Impact on the Coastal Environment of Marine Aggregates Mining'. International Journal of Environmental Studies, vol. 59 no. 3, pp. 297-322. doi:10.1080/00207230211304

Cruz-Motta, JJ, \& Collins, J 2004, 'Impacts of dredged material disposal on a tropical soft-bottom benthic assemblage'. Marine Pollution Bulletin, vol. 48, no. 3, pp. 270-280. doi:https://doi.org/10.1016/j.marpolbul.2003.08.002

Erftemeijer, PLA, Riegl, B, Hoeksema, BW, \& Todd, PA 2012, 'Environmental impacts of dredging and other sediment disturbances on corals: A review'. Marine Pollution Bulletin, vol. 64, no. 9, pp. 1737-1765. doi:10.1016/j.marpolbul.2012.05.008

Fariansyah, M 2019, Lahan bekas tambang di Belitung menjadi kawasan wisata mangrove. Retrieved from https://www.greeners.co/berita/lahan-bekas-tambang-menjadi-kawasan-wisata/

Febrianto, A, Baskoro, MS, Simbolon, D, \& Haluan, J 2015, 'The impact of tin mining activities on squid (Uroteuthis chinensis) Fishing Ground in South Bangka'. International Journal of Sciences: Basic and Applied Research vol. 23, pp. 283-293.

Hortle, KG, \& Person, RG 1990, 'Fauna of the Annan River System, far North Queensland, with reference to the Impact of Tin Mining. I. Fishes.' Marine and Freshwater Research, vol. 41, no. 6, pp. 677-694.

Newell, R, Seiderer, L, \& Hitchcock, D 1998, 'The impact of dredging works in coastal waters: a review of the sensitivity to disturbance and subsequent recovery of biological resources on the seabed'. Oceanography and Marine Biology vol. 36, pp. 135-158.

Puttiwongrak, A, Suteerasak, T, Mai, PK, Hashimoto, K, Gonzalez, JC, Rattanakom, R, \& Prueksakorn, K 2019, 'Application of multimonitoring methods to investigate the contamination levels and dispersion of $\mathrm{Pb}$ and $\mathrm{Zn}$ from tin mining in coastal sediments at Saphan Hin, Phuket, Thailand.' Journal of Cleaner Production, vol. 218, pp. 108-117. doi:https://doi.org/10.1016/j.jclepro.2019.01.254

Rustidja, ES, Purnamawati, A, \& Setiawati, R 2017, 'Investment promotion for community economic development of special economic zone: Study of Sez Mandalika and Bitung in Indonesia'. European Journal of Economics and Business Studies, vol. 3 , no. 2, pp. 138-147.

Syari, I, Sudrajat, J, Octaviano, H, Hutahaean, B, Adnis, R, \& Taruk Allo, O 2019, Implementation of offshore reclamation methods on an old tin mining area on Bangka Island, Indonesia. in A Fourie \& M Tibbett (eds), Proceedings of the 13th International Conference on Mine Closure.

Yusuf, M, Hudatwi, M, Adi, W, \& Robin 2021, 'Distribution of water turbidity concentrations and phosphate content in tanah merah beach and semujur island waters, Central Bangka Regency'. Earth and Environmental Science, vol. 718, no. 1, pp. 012024. doi:10.1088/1755-1315/718/1/012024 